\title{
LAW OF THE SEA AND ENVIRONMENTAL LAW ACTING TOGETHER: EXPERIENCE OF LAYING SUBMARINE CABLES IN THE ARCTIC
}

\author{
DARIA SHVETS \\ PhD Candidate \\ Universitat Pompeu Fabra \\ daria.shvets01@estudiant.upf.edu
}

Reception date: $13^{\text {th }}$ April $2018 / 7^{\text {th }}$ September 2018

\begin{abstract}
All states have the right to lay submarine cables on the seabed according to the United Nations Law of the Sea Convention 1982 (LOSC). Unlike submarine pipelines, cables are generally considered being environmentally friendly, having minimum impact on the marine environment. Currently, there are several projects on submarine cables planned to be laid in the Arctic. In particular, the Quintillion Subsea Cable System is an ongoing large-scale project, which major part will go through the Arctic waters. Despite mostly local and moderate disturbance to the environment in other regions, it causes certain concerns regarding the influence on the Arctic environment due to its unique and sensible ecosystem. The LOSC does not separate the Arctic from other regions, and cables are laid there following the same conditions as well as in other parts of the World Ocean. This article aims to examine the international legal regime of submarine cables in the context of the ongoing cable projects in the Arctic as well as to consider the applicability of the precautionary principle and the provisions of the Polar Code for ensuring the protection of the Arctic environment.
\end{abstract}

RESUM: Tots els estats tenen dret a establir cables submarins al fons marí d'acord amb la Convenció de les Nacions Unides sobre el Dret del Mar de 1982 (CNUDM). A diferència de les canonades submarines, els cables generalment es consideren respectuosos amb el medi ambient i tenen un impacte mínim en el medi marí. Actualment, hi ha diversos projectes sobre cables submarins previstos per a la instal-lació a l'Àrtic. En particular, el sistema de cable submarí 
de Quintillion està en curs en gran escala, la major part de la qual es collocarà a l'Àrtic. Malgrat la perturbació local i moderada en el medi ambient d'altres regions, hi ha certes preocupacions sobre l'efecte de l'esmentada construcció sobre l'entorn àrtic, donat el seu ecosistema únic i sensible. La CNUDM no separa l'Àrtic d'altres regions i els cables s'exposen seguint les mateixes condicions que a les altres parts de l'Oceà Mundial. Aquest article pretén examinar el règim jurídic internacional de cables submarins en el context del projectes de cable en curs a l'Àrtic, així com considerar l'aplicabilitat del principi de precaució i les disposicions del Codi Polar per garantir la protecció de l'entorn àrtic.

RESUMEN: Todos los estados tienen el derecho a colocar cables submarinos en el fondo marino de acuerdo con la Convención de las Naciones Unidas sobre el Derecho del Mar de 1982 (la CNUDM). A diferencia de las tuberías submarinas, los cables generalmente se consideran respetuosos con el medio ambiente y tienen un impacto mínimo en el medio marino. Actualmente, hay varios proyectos sobre cables submarinos que se planean instalar en el Ártico. En particular, el sistema de cable submarino Quintillion es un proyecto a gran escala en curso, cuya mayor parte se colocará en el Ártico. A pesar de la perturbación en su mayoría local y moderada el medio ambiente de otras regiones, dicha construcción causa ciertas preocupaciones con respecto a la influencia en el medio ambiente ártico, debido a su ecosistema único y sensible. La CNUDM no separa el Ártico de otras regiones y los cables se colocan allí siguiendo las mismas condiciones que en otras partes del Océano Mundial. Este artículo tiene como objetivo examinar el régimen jurídico internacional de los cables submarinos en el contexto del proyecto de cable en el Ártico, así como considerar la aplicabilidad del principio de precaución y las disposiciones del Código polar para garantizar la protección del medio ambiente ártico.

KEY WORDS: Submarine cables - LOSC - Arctic - Environmental protection Polar code - Law of the sea. 
PARAULES CLAU: Cables submarins - LOSC - Àrtic - Protecció mediambiental - Codi polar - Dret del mar.

PALABRAS CLAVE: Cables submarinos - LOSC - Ártico - Protección del medio ambiente - Código polar - Derecho del mar.

\section{LIST OF CONTENTS:}

I. Introduction. II. Historical background. 1. The 1884 Convention for the Protection of Submarine Telegraph Cables. 2. The 1958 Geneva Conventions a) Geneva Convention on the Continental Shelf 1958. b) Geneva Convention on the High Seas 1958. III. Current legal regulation of submarine cables under the LOSC. 1. Maritime zones under the coastal states jurisdiction. 2. Maritime zones where coastal states enjoy certain rights. 3. Maritime zones beyond coastal states jurisdiction. IV. Submarine cables and the environment. V. Projects of submarine cables in the Arctic. 1. Completed projects. 2. Proposed projects. 3. The current project of Quintillion Subsea Cable System. VI. Environmental law aspect of submarine cables in the Arctic. 1. Application of the precautionary principle. 2. The Polar Code requirements for cable ships. VII. Conclusion. VIII. Bibliography

\section{INTRODUCTION}

Communications play an essential role in the life of modern society. It is hard to imagine our community without the present-day means of communication linking people and making the world connected. Individuals, private entities, and governments geographically located in different parts of the world can have business with their partners who are all the same can reside elsewhere. Internet and telephony, text and voice messages, international videoconferences and multimillion-dollar banking transactions, terabytes of photos and videos, as well as other traffic data that runs daily around the world, requires modern technology and reliable infrastructure ready to transmit an overwhelming amount of information with a high speed. To date, this infrastructure is represented by fiber-optic submarine cables transmitting around $97 \%$ of all global traffic ${ }^{1}$.

Modern submarine cables ensure and provide the world with stable communications. In the event of a break or damage to a submarine cable,

1 Douglas Burnett, Tara Davenport, Robert Beckman, Submarine cables: The Handbook of Law and Policy, International Martinus Nijhoff. Leiden, 2014, p.3; Elena Perez-Alvaro, "Unconsidered Threats to Underwater Cultural Heritage: Laying Submarine Cables", in Rosetta, vol.14, 2013, p. 4. 
disruptions can affect large territories and cause interruptions in the communications for millions of people and organizations around the world ${ }^{2}$. Usually, it is not noticeable to ordinary users, because, in the event of an incident, the information will be rerouted to another, alternative cable which can take the capacity of the damaged one. However, the transmission speed can be reduced, and normal operations would be delayed or postponed until the normal operation of the damaged cable is restored. The statistics show that about 200 fiber-optic submarine cables are damaged every year ${ }^{3}$, given that the total amount of submarine telecommunications cables currently existing on the seabed of the World Ocean is around $400^{4}$.

Modern submarine cables can transmit various types of information in contrast to the first telegraph cables which only provided with the opportunity for transmitting voice calls through the telegraph. There are two types of submarine cables which are used and laid on the seabed nowadays: telecommunications cables and power cables.

Telecommunications cables represent the majority of international submarine cables. They are used for transmitting voice calls, messages, Internet, and other data. Power cables are designed to supply various structures with electricity. For instance, they ensure the operations of oil and drilling platforms at sea. Power cables are usually less long than telecommunications cables and used for local needs connecting the platform with the mainland.

Telecommunications and power cables, apart from their initial designation are also used for adjacent activities. For instance, they serve for collecting data on the condition of the state of the marine environment, marine scientific research, military aims, and some other purposes. Sometimes cables contain sensors measuring the quality of water and sending data on the salinity, temperature, or

\footnotetext{
2 Maura Conway, L. Lee Jarvis, Orla Leha, "Terrorists' Use of the Internet: Assessment and Response", in NATO Science for Peace and Security Series E: Human and Societal Dynamics, vol.136, 2017, p.17.

${ }^{3}$ Douglas Burnett, "Note to Navy: It's time to pay attention to security for undersea cablescrucial to global communications and commerce, and vital to our national interests", in Proceedings Magazine of the US Naval Institute, vol. 137/8/1,302, 2011, p.67.

${ }^{4}$ https://www.submarinecablemap.com/ [Retrieved on 14 November 2018].
} 
any other characteristics ${ }^{5}$. Some submarine cables also help to predict tsunamis and other natural disasters ${ }^{6}$.

Submarine cables is a relatively undiscovered area of the international law of the sea. Not surprisingly the legal perspective of the activity related to submarine cables is currently attracting the attention of legal scholars ${ }^{7}$. Notwithstanding the type of submarine cable and the information it transmits, relatively little attention is given to submarine cables in the public international law. The legal regulation is limited by several articles of the $\operatorname{LOSC}^{8}$ and the occasional mention of submarine cables by several international agreements devoted to different aspects of the law of the sea. At the same time, submarine cables are interesting to examine from the environmental point of view. Especially in the Arctic where they appear as a new emerging activity of the ocean use.

The present article aims to examine the environmental dimension of the activity of laying submarine cables in the Arctic and the applicability of the precautionary principle in relation to it. The analysis will be structured as follows. The first part will be devoted to the history of the legal regulation of submarine cables. Second, an overview of the legal regime of submarine cables under the LOSC will be given. Afterward submarine cables will be examined from the environmental point view followed by the examples of planned and already implemented projects in the Arctic. Finally, the use of environmental law

\footnotetext{
${ }^{5}$ Rhett Butler, eds., "The scientific and societal case for the integration of environmental sensors into new submarine telecommunication cables", Joint Task Force on Green Cables ITU/WMO/UNESCO/IOC publication, 2014, p. 24, <http://www.itu.int/dms_pub/itu-t/opb/tut/TTUT-ICT-2014-03-PDF-E.pdf> [Retrieved on 14 November 2018].

${ }^{6}$ Howe B., Panayotou K., "Harnessing submarine cables to save lives", The UNESCO Courier, e-ISSN 2220-2293, 2017, <https://en.unesco.org/courier/2017-october-december/harnessingsubmarine-cables-save-lives> [Retrieved on 10 April 2018].

${ }^{7}$ See Youri Van Logchem, "Submarine Telecommunication Cables in Disputed Maritime Areas", in Ocean Development and International Law, vol. 45, 2014; Douglas Burnett, "Recovery of Cable Repair Ship Cost Damages from Third Parties That Injure Submarine Cables", in Tulane Maritime Law Journal, vol. 35, 2010; Tara Davenport, "Submarine Cables, Cybersecurity and International Law: An Intersectional Analysis", in Catholic University Journal of Law and Technology, vol. 24, 2015; Kingsley Ekwere, "Submarine Cables and the Marine Environmental: Enhancing Sustainable and Harmonious Interactions", in China Oceans Law Review, vol. 2016, 2016.

${ }^{8}$ The United Nations Convention on the Law of the Sea (LOSC), concluded in Montego Bay on 10 of December 1982, entered into force on 16 of November 1994, 1833 UNTS 3; 21 ILM 1261, 1982.
} 
and the precautionary principle will be justified in relation to submarine cables activities in the Arctic followed by the conclusion.

\section{HISTORICAL BACKGROUND}

First submarine cables appeared in the mid-nineteenth century aimed at connecting European countries between each other. In particular, in 1850 the first international telegraph cable was laid between Great Britain and France ${ }^{9}$. Simultaneously in another part of the world first cables connecting Canada with the United States were laid $^{10}$. In 1862, a few years later, the first Russian submarine cable with a length of 32 kilometers appeared on the bottom of the river Northern Dvina followed by the first cable that crossed the Caspian Sea in $1879^{11}$. That time already it became clear that the activity relating to submarine cables needs comprehensive legal regulation. Thus, starting from the beginning of the nineteenth century the international society started making the first attempts to regulate submarine cables.

\section{The 1884 Convention for the Protection of Submarine Telegraph Cables}

An initiative of drafting an international agreement for regulating activities relating to submarine cables belonged to France, and after this initiative, a special conference was convened in $1882^{12}$. The negotiations in the framework of this conference resulted in the signature of the Convention for the Protection of Submarine Telegraph Cables by 26 states in $1884^{13}$. It was the first and quite successful attempt of international law to regulate activities relating to submarine cables. The convention has elaborated several instruments which are still kept and used by modern law of the sea. For instance, the rule that all other vessels shall keep a distance of one nautical mile from the vessel

\footnotetext{
${ }^{9}$ Douglas Burnett, Tara Davenport, Robert Beckman, Submarine cables: The Handbook...cit. p.20.

10 Miso Mudrić., "Rights of States regarding underwater cables and pipelines", in Australian resources and energy Law Journal, vol. 29, 2010, p.235.

${ }^{11}$ Elena Guseva, "Istoriya podvodnogo cabelestroyeniya", in Cable-news journal, vol.4, 2010.

12 Constantine John Colombos, The International Law of the Sea (Russian translation), Progress. Moscow, 1975, p.334.

${ }^{13}$ International Convention for the Protection of Submarine Telegraph Cables 1884, concluded in Paris on 14 of March 1884, entered into force on the 1 of May 1888, 163 CTS 391 [French], 24 Stat.989; TS No. 380 (S).
} 
engaged in laying or repairing operations (the so-called "cable ship") ${ }^{14}$. The International Regulations for Preventing Collisions at Sea (COLREGs) $1972^{15}$ currently have a similar provision. Rule $3(\mathrm{~g})$ says that the vessel engaged in submarine cable operations is considered as a vessel:

"restricted in her ability to manoeuvre as required by these Rules and is, therefore, unable to keep out of the way of another vessel."

It means that all other vessels shall keep a distance from a cable ship when it performs its operations. However, in contrast to the 1884 Convention, it does not set a minimum distance to be kept by other vessels. Thus, in some issues, the Convention for the Protection of Submarine Telegraph Cables even surpasses modern international law agreements.

\section{The 1958 Geneva Conventions}

The new milestone in the development of the legal regime of activities relating to submarine cables at the universal level originates from the conclusion of the Geneva Conventions of 1958. Two of them, namely the Convention on the Continental Shelf ${ }^{16}$ and the Convention on the High Seas ${ }^{17}$, contained some provisions regarding submarine cables.

\section{a) Geneva Convention on the Continental Shelf 1958}

In the framework of the Convention on the Continental Shelf 1958, a new provision relating to submarine cables laid on the continental shelf appeared which reads as follows:

\footnotetext{
${ }^{14}$ Article 5 of the 1884 Convention for the Protection of Submarine Telegraph Cables stipulates that "When a ship engaged in repairing a cable exhibits the said signals, other vessels which see them, or are able to see them, shall withdraw to or keep beyond a distance of one nautical mile at least from the ship in question, so as not to interfere with her operations".

${ }^{15}$ Convention on the International Regulations for Preventing Collisions at Sea (COLREGs), concluded 20 of October 1972, entered into force 15 of July 1977, 1050 UNTS 16.

${ }^{16}$ Convention on the Continental Shelf 1958, concluded in Geneva on 29 of April 1958, entered in to force on 10 of June 1964, 15 UST 471; 499 UNTS 311.

${ }^{17}$ Convention on the High Seas, concluded in Geneva on 29 of April 1958, entered into force on 30 of September 1962, UNTS 450 (p. 11).
} 


\begin{abstract}
"Subject to its right to take reasonable measures for the exploration of the continental shelf and the exploitation of its natural resources, the coastal State may not impede the laying or maintenance of submarine cables or pipelines on the continental shelf." ${ }^{\text {18 }}$
\end{abstract}

The concept of the "continental shelf" and the resources of the continental shelf did not exist in the international law of the sea before. With the appearance of this convention, states received certain rights over those territories and their resources which previously were considered as territories not under the jurisdiction of any state. Accordingly, a problem between the rights of the coastal state over new maritime space it recently received and the right to lay submarine cables on the continental shelf exercised by other states arouse. Since that moment it became clear that possible routes of submarine cables could pass through the continental shelf which means the participation of the coastal state in the process of laying a new cable and exercise of certain rights. Among such rights is to take reasonable measures to explore the continental shelf. This approach was later reflected in the provisions of Article 79 of the LOSC.

\title{
b) Geneva Convention on the High Seas 1958
}

The Convention on the High Seas, similar to the Convention on the Continental Shelf, regulated legal issues related to the activities of laying and maintaining submarine cables in the high seas. Needless to say that at that time the International Seabed Area (meaning the seabed of the high seas where cables are literally laid) was not yet designated as a separate maritime area.

Article 26 of the Convention on the High Seas ensured the freedom to lay submarine cables on the high seas by any state, either coastal or land-locked. Also, the convention had four other articles relating to submarine cables which partially repeated the provisions of the Convention on the Continental Shelf and partially the provisions of the Convention on the Protection of Submarine Telegraph Cables. Among them are provisions requiring to establish the duty of states to set in their national legislation legal rules on liability for damage to

\footnotetext{
${ }^{18}$ Convention on the Continental Shelf 1958, Article 4.
} 
submarine cables and receipt of compensation, in case it can be proved that a person sacrificed an anchor, a net or any other fishing gear to prevent damage to a submarine cable. There is also the right to take reasonable measures for the exploration of the continental shelf and the exploitation of its natural resources. However, when performing these activities, the coastal state may not impede the laying or maintenance of other cables or pipelines laid in the same area. Such a point and incidental regulation against the general norms of the convention is unusual, but considering the international character of the high seas as a space free for all states, it was a forced measure dictated by the necessity to ensure coastal states' rights over resources of the continental shelf. These provisions are also preserved in the $\operatorname{LOSC}^{19}$.

\section{CURRENT LEGAL REGULATION OF SUBMARINE CABLES UNDER THE}

\section{LOSC}

Currently, the legal regime of submarine cables consists of several articles of the LOSC which takes precedence over the Geneva Conventions ${ }^{20}$. The LOSC is an authoritative international agreement which currently has 168 participants ${ }^{21}$. Being the most ambitious document ever regulating the issues of the law of the sea, it has united the provisions from all the areas and presented them in a single document. However, the LOSC does not contain a separate chapter or a separate section on the regulation of submarine cables. The norms concerning various aspects of submarine cables are encountered throughout the convention in different chapters.

All the provisions of the LOSC devoted to submarine cables can be classified on a territorial basis since the legal regulation varies depending on the maritime zone where submarine cable is laid. First is maritime zones under the sovereignty of the coastal/archipelagic state where it can exercise its jurisdiction (territorial sea and archipelagic waters). Second is maritime zones that are not

\footnotetext{
${ }^{19}$ LOSC, Article 115.

${ }^{20}$ LOSC, Article 311.

${ }^{21}$ Chronological lists of ratifications of, accessions and successions to the Convention and the related Agreements, Division for Ocean Affairs and the Law of the Sea, available at $<$ http://www.un.org/depts/los/reference files/chronological lists of ratifications.htm> [Retrieved on 14 November 2018].
} 
under the sovereignty of coastal states but where they exercise certain rights (exclusive economic zone, contiguous zone, and continental shelf). Third, maritime zones not under the jurisdiction of any state reserved for use by any state including landlocked (high seas and international seabed area). Currently, with respect to submarine cables, the LOSC establishes the following provisions.

\section{Maritime zones under the coastal states jurisdiction}

Coastal states have sovereignty over the territorial sea. Within this maritime zone, they are entitled to regulate all activities of all entities, including activities for laying, operating and repairing damaged submarine cables ${ }^{22}$. In addition, coastal states have the right to adopt laws and regulations relating to the right of innocent passage through the territorial sea exercised by other states, including provisions for the protection of submarine cables. In particular, such laws and regulations must comply with the LOSC and other norms of international law. However, this right of a coastal state is limited. The LOSC specifies that laws and regulations established by the coastal state shall not apply to the design, construction, manning or equipment of foreign ships unless they are giving effect to generally accepted international rules or standards ${ }^{23}$. Although the proposal to include a definition of "generally accepted international rules or standards" appeared during the negotiations on the text of the convention ${ }^{24}$ it was not reflected in the final version of the LOSC. Thus, the coastal state may only implement and elaborate in its domestic legislation internationally established rules and standards without creating any new provisions beyond the scope of those contained in international agreements. Generally, Article 21 regulating submarine cables in the territorial sea has multiple aims: to maintain the integrity of cable systems, to avoid breaks in communications, protect cables in areas used for navigation, and to protect the marine environment ${ }^{25}$.

\footnotetext{
${ }^{22}$ LOSC, Article 2(1).

${ }^{23}$ LOSC, Article 21 (2).

${ }^{24}$ Myron Nordquist, Satya Nandan, Shabtai Rosenne, eds., The United Nations Convention on the Law of the Sea 1982: A Commentary, Dordrecht, Boston and London: Martinus Nijhoff Publishers, 1993, vol. II, p. 202.

${ }^{25}$ Myron Nordquist, Satya Nandan, Shabtai Rosenne, eds.... cit., p. 200.
} 
The archipelagic state also has sovereignty over archipelagic waters ${ }^{26}$. It can regulate certain activities in archipelagic waters in order to protect submarine cables. It shall respect existing agreements with other states and shall recognize traditional fishing rights and other legitimate activities of the immediately adjacent neighboring states. The term "other legitimate activities" is not defined by the LOSC but it must apply to those activities which had been taking place repeatedly in this maritime zone before the regime of archipelagic waters was established. For example, the military activities would be considered as possible legitimate activities ${ }^{27}$. Laying of submarine cables is not a repeating process but rather a single aim project implemented on an individual basis. It means that laying of submarine cables cannot be considered as a traditional right of neighboring states. At the same time, once the cable is laid, it requires certain works on maintenance and repair. Thus, the second part of Article 51 (2) deserves special attention:

"An archipelagic State shall respect existing submarine cables laid by other States and passing through its waters without making a landfall. An archipelagic State shall permit the maintenance and replacement of such cables upon receiving due notice of their location and the intention to repair or replace them." ${ }^{28}$

This provision is explained by the fact that before the adoption of the LOSC, the notion "archipelagic waters" did not exist in international law, but submarine cables in such parts of the seabed were already laid. Since the archipelagic states obtained sovereignty over these maritime areas, it was decided in the negotiation process to include this article in the final text of the LOSC ${ }^{29}$. As for the laying of new submarine cables in archipelagic waters, the LOSC does not contain specific provisions. However, given the fact that the archipelagic waters are under the sovereignty of the archipelagic state, it can be concluded that the

\footnotetext{
${ }^{26}$ LOSC, Article 49(1).

${ }^{27}$ Alexander Proelss, United Nations Convention on the Law of the Sea: A Commentary, $1^{\text {st }}$ edition, Leiden: Beck/Hart/Nomos, 2017, p.387.

${ }^{28}$ LOSC, Article 51(2).

${ }^{29}$ Myron Nordquist, Satya Nandan, Shabtai Rosenne, eds.... cit. p. 449.
} 
archipelagic states have the right to establish conditions for laying submarine cables in these maritime areas.

\title{
2. Maritime zones where coastal states enjoy certain rights
}

In the exclusive economic zone, coastal states have sovereign rights and jurisdiction ${ }^{30}$, including certain rights concerning submarine cables. In accordance with article $58(1)$ :

\begin{abstract}
"In the exclusive economic zone all States, whether coastal or land-locked, enjoy, subject to the relevant provisions of this Convention, the freedoms referred to in article 87 of navigation and overflight and of the laying of submarine cables and pipelines, and other internationally lawful uses of the sea related to these freedoms, such as those associated with the operation of ships, aircraft and submarine cables and pipelines, and compatible with the other provisions of this Convention".
\end{abstract}

It is worth noting that Article 87 establishes the rights and freedoms of states in the high seas. Therefore, in the exclusive economic zone states enjoy the freedoms of the high seas, but with certain exceptions. One of such exceptions is the provision that states when laying submarine cables, must respect the rights and obligations of the coastal state and comply with its laws and regulations. It one more time highlights the consistent approach of the LOSC to keep a balance between the rights of a coastal state and rights of all other members of the convention exercising certain freedoms in the exclusive economic zone. During the negotiations process, there was a proposal to make laying of submarine cables and pipelines subject to coastal states' consent ${ }^{31}$. However, this proposal was not supported by other countries, and currently, the exclusive economic zone is free for laying submarine cables and does not require an expressed consent of the coastal state.

\footnotetext{
${ }^{30}$ LOSC, Article 55.

${ }^{31}$ A/AC.38/SC.II/L.34, part 2, paragraphs (4) and (6), reproduced in III SBC Report 1973, at 71, 73 (China).
} 
The continental shelf is an area that deserves special attention. Article 79 is the only article in the LOSC entirely devoted to submarine cables to cover several aspects. It provides that all states have the right to lay submarine cables and pipelines on the continental shelf. In addition, the exercise of the rights of a coastal state with respect to the continental shelf should not prejudice the interests of navigation and other rights and freedoms of other states provided by the LOSC, or lead to any unjustifiable interference with their implementation ${ }^{32}$. It also relates to submarine cables. The coastal state, in turn, can take "reasonable measures" to explore and develop its natural resources and prevent, reduce, and control pollution from pipelines ${ }^{33}$. What does the word "reasonable measures" mean, and what exactly can the coastal state undertake, is not always clear.

Part 3 of Article 79 of the LOSC is of particular interest. It contains the following rule:

"The delineation of the course for the laying of such pipelines on the continental shelf is subject to the consent of the coastal State".

This section refers only to pipelines, which means that the provision on the consent of the coastal state to determine the route does not apply to cables. However, the International Law Commission in its Draft Articles of 1956 has specified that "the coastal state is obliged to permit the laying of cables and pipelines on the floor of its continental shelf, but ... it can impose conditions as to the route to be followed, in order to prevent undue interference with the exploitation of the natural resources of the seabed and subsoil. Clearly, cables and pipelines must not be laid in such a way as to hamper navigation" ${ }^{34}$. Thus, it is not entirely clear whether submarine cables can be laid on the continental shelf freely without obtaining a consent from the coastal state. The coastal state may still impose requirements on the route of a cable. Cable companies shall also take into account cables and pipelines already laid on the seabed when

\footnotetext{
${ }^{32}$ LOSC, Article 78 (2).

${ }^{33}$ LOSC, Article 79 (2).

${ }^{34}$ Report of the International Law Commission covering the work of its eighth session (A/3159), Article 70 and Commentary, II YB ILC 1956, p. 299.
} 
laying new submarine cables on the continental shelf. In particular, the possibility of repairing existing cables and pipelines (in accordance with paragraph 5 of Article 79 of the LOSC) should not be impaired.

Finally, the maritime space titled the contiguous zone consists of only one article where there is no mention of submarine cables. Thus, it does not contribute to submarine cables legal regime.

\section{Maritime zones beyond coastal states jurisdiction}

Articles 87 and 112 of the LOSC recognize the right of all states to freely lay submarine cables and pipelines on the bottom of the high seas, beyond the continental shelf. In fact, this freedom now refers to the regime of the international seabed area titled the "Area", the maritime zone created by the LOSC since cables are laid directly on the seabed of the ocean. Thus, two maritime zones such as the high seas and the Area geographically occupy the same space with the difference that the regime of the high seas relates to the water column while the regime of the Area applies to the seabed. This freedom is not absolute and has its limits. Needless to say that under the Convention on the High Seas in contrast to the LOSC the freedom to lay submarine cables was unlimited $^{35}$. The main limit is that a state planning to construct a submarine cable is obliged to pay due attention to the already existing submarine cables and not interfere with the repair possibilities of such cables. All states should also take into account the interests of other states exercising the rights enshrined in the LOSC concerning activities in the Area ${ }^{36}$.

The provisions of the LOSC relating to "activities" in the Area and to "general conduct" in the Area are different in the terminology of the LOSC. Activities in the Area shall mean all activities for the exploration and exploitation of the seabed by Article 1 of the LOSC. All other activities, including laying of submarine cables, shall be governed by the article 138 "General conduct of States in relation to the Area". The latter indicates that it is determined not only by the provisions of the LOSC but also by the principles embodied in the

\footnotetext{
${ }^{35}$ Alexandr Proelss, United Nations Convention on the Law of the Sea...cit. p. 682.

${ }^{36}$ LOSC, Article 87(2).
} 
Charter of the United Nations ${ }^{37}$ and according to other rules of international law in the interests of maintaining peace and security and promoting international cooperation and mutual understanding in this maritime space. At the same time, national legislation of many states cannot be considered as developed neither with regard to "general conduct" in the Area nor to submarine cables in particular ${ }^{38}$.

There is one more aspect necessary to mention. Even though the LOSC uses the wording "states have the right to lay submarine cables"39, in practice cables are laid and operated by cable-laying companies (the "cable companies"). They are legal entities with or without state participation. Thus, concerning this aspect, the LOSC shall be interpreted extensively ${ }^{40}$.

In addition to the LOSC, certain provisions aimed at regulating submarine cables are contained in other international instruments, such as the 1972 Convention on International Regulations for Preventing Collisions at Sea ${ }^{41}$, the Convention on the Prevention of Marine Pollution by Dumping of Wastes and Other materials of $1972^{42}$, the Convention on the Protection of the Underwater Cultural Heritage of $2001^{43}$, the resolutions of $\mathrm{IMO}^{44}$ and some other

37 United Nations, Charter of the United Nations, 24 October 1945, 1 UNTS XVI, <http://www.refworld.org/docid/3ae6b3930.html> [Retrieved 14 November 2018].

${ }^{38}$ Robert Beckman, "Submarine Cables - A Critically Important but Neglected Area of the Law of the Sea", paper presented at 7 the International Conference on Legal Regimes of Sea, Air, Space and Antarctica, 15-17 of January 2010, New Delhi, available at $<$ https://cil.nus.edu.sg/wp-content/uploads/2010/01/Beckman-PDF-ISIL-Submarine-Cables-rev8-Jan-10.pdf> [Retrieved on 14 November 2018], pp. 1-17, p. 14.

${ }^{39}$ See Articles 51 (2), 58 (1), 79, et cetera.

40 Alexander Proelss, United Nations Convention on the Law of the Sea...cit. p. 781; Myron Nordquist, Satya Nandan, Shabtai Rosenne eds., United Nations Convention on the Law of the Sea 1982: A Commentary, Dordrecht, Boston and London: Martinus Nijhoff Publishers, vol. III, 1993, p. 264.

${ }^{41}$ Convention on the International Regulations for Preventing Collisions at Sea (COLREGS), adopted 20 of October 1972, entered into force 15 of July 1977, 1050 UNTS 16, Rules 1 (a),(b), 3 (i), (g), 7, 10.

42 Convention on the Prevention of Marine Pollution by Dumping of Wastes and Other Matter, adopted 13 of November 1972, entered into force 30 of August 1975, 26 UST 2403, 1046 UNTS 120, 11 ILM 1294 (1972), Articles 3, 3 (b), 3.3, 13.

${ }^{43}$ Convention on the Protection of the Underwater Cultural Heritage, concluded 2 of November 2001, entered into force 2 of January 2009, 2562 UNTS, Article 1 (b).

44 See International Maritime Organization, Circular SN.1/Circ.282 on the Prohibition of Anchoring in the Straits of Malacca and Singapore, 27 of November 2009, Ref. T2-OSS/2.7.1, $<$ https://cil.nus.edu.sg/wp-content/uploads/2009/10/SN-1-Circ-282-INFORMATION- 
international agreements. However, the LOSC constitutes the basis of the submarine cables legal regime and thus occupies its central place.

\section{SUBMARINE CABLES AND THE ENVIRONMENT}

In the scientific literature, it is recognized that submarine cables do not cause serious harm to the environment ${ }^{45}$. In addition, the joint report of the United Nations Environment Program (UNEP) and the International Cable Protection Committee emphasizes that:

"the small physical size of a telecommunications cable implies that its environmental footprint is likely to be small and local ... a suggestion that is borne out by several studies" 46 .

Marine organisms quickly adapt to submarine cables laid in the vicinity, and after a short period, they cover the cables completely, turning them into a part of the ocean floor. Even the process of laying cables and their burying required in shallow waters causes minimal damage to the inhabitants of the sea ${ }^{47}$.

Generally, in the context of the environmental impact from submarine cables, they are considered as friendly to the marine environment, causing less impact on the seabed than pipelines ${ }^{48}$. Unlike submarine pipelines, whose damage will inevitably lead to oil spills and ecological catastrophe, submarine cables are not capable of causing such harm. The second item is that the size of submarine cables is less than of pipelines which means smaller disturbance of seabed inhabitants during the installation process. One more thing can be distinguished

International Maritime Organization, Sub-Committee on Safety of Navigation $46^{\text {th }}$ session, Agenda item 9, (SMCP), <http://www.segeln.co.at/media/pdf/smcp.pdf> [Retrieved on 14 November 2018], et cetera.

45 Elena Perez-Alvaro, "Unconsidered Threats..." cit. p.18; Miso Mudrić., "Rights of States regarding..." cit. p.240; Bruce C. Heezen, G. Leonard Johnson, "Alaskan Submarine Cables: A Struggle with a Harsh Environment”, Arctic, vol. 22, No. 4, 1969, pp. 413-424.

${ }^{46}$ Lionel Carter, Douglas Burnett, Stephen Drew, Graham Marle, Lonnie Hagadorn, Deborah Bartlett-McNeil D., Nigel Irvine," Submarine Cables and the Oceans - Connecting the World", in UNEP-WCMC Biodiversity Series, vol. 31, 2009, p.9.

${ }^{47}$ Irina Kogan, Charles Paull, Linda Kuhnz, Erica Burton, Susan Von Thun, H. Gary Greene, James Barry, "ATOC/Pioneer Seamount cable after 8 years on the seafloor: Observations, environmental impact", in Continental Shelf Research, vol. 26, 2006, pp. 9-13.

${ }^{48}$ Y. Van Logchem, "Submarine Telecommunications Cables in Disputed Maritime Areas", Ocean Development \& International Law, 45, 2014, pp. 107-122, p. 110. 
through the process of operation when submarine cables cause less warmth, electromagnetic waves, and noise for the adjacent environment ${ }^{49}$.

Notwithstanding, many states require preliminary environmental impact assessment before issuing a permit to lay a submarine cable in their maritime zones $^{50}$. Environmental impact assessment is "an analysis of a project's effects on the natural environment and its purpose is to ensure that any environmental effects of cable laying and maintenance are taken into account before authorization is provided to lay a cable on the seabed"51.

Such behavior of coastal states is logical provided that submarine cables can still endanger the marine environment. Especially in the long-term perspective and in one of the unique environmental areas in the world such as the Arctic. The provisions of the LOSC provide with the general regime of submarine cables and do not distinguish laying of submarine cables in the Arctic from other parts of the World Ocean. However, the Arctic environment is unique and vulnerable. Some authors note that submarine cables can negatively influence the marine environment ${ }^{52}$. The OSPAR Commission in 2009 published an environmental impact assessment of submarine cables on the environment ${ }^{53}$. Based on this document, the impact of electromagnetic fields and thermal radiation on organisms sensitive to these types of influence is still unknown. In some reports, it is argued that the whole effect on maritime organisms' behavior from submarine cables' exposure is largely unknown ${ }^{54}$. In other words, light,

\footnotetext{
49 Irina Kogan, Charles Paull, Linda Kuhnz, Erica Burton, Susan Von Thun, H. Gary Greene, James Barry, "ATOC/Pioneer Seamount cable after 8 years on the seafloor..." cit. p.10.

50 For instance, Federal Law "On the Exclusive Economic Zone of the Russian Federation" dated 17 December 1998 No. 191-FZ contains the requirement of state ecological expertise in every case of laying submarine cables in this maritime area. See Article 27, paragraph 3. See also Chinese Order No. 3 of the State Oceanic Administration titled "Measures of the State Oceanic Administration for the Implementation of the Administrative Provisions Governing the Laying of Submarine Cables and Pipelines" dated 26 August 1992, Article 9.

51 Lionel Carter, Douglas Burnett, Stephen Drew, Graham Marle, Lonnie Hagadorn, Deborah Bartlett-McNeil D., Nigel Irvine," Submarine Cables..." cit. p.29.

52 Thomas Worzyk, Submarine Power Cables: Design, Installation, Repair, Environmental Aspects, Springer. Dordrecht, Heidelberg, London, New York, 2009.

53 OSPAR Commission, "Assessment of the environmental impacts of cables", in Biodiversity Series, vol.1, 2009.

${ }^{54}$ Norval Collins, "Assessment of Potential Ecosystem Effects from Electromagnetic Fields (EMF) Associated with Subsea Power Cables and TISEC Devices in Minas Channel", prepared by CEF Consultants Ltd. for Fundy Ocean Resource Centre for Energy (FORCE), Halifax, 2012, p. 33.
} 
noise, vibration, physical disturbance, occasional discharge of harmful substances by a cable ship and other factors can influence marine organisms. For some individual species, the effect is unpredictable. Therefore, the possible significant negative impact caused by submarine cables to the marine environment cannot be excluded.

Generally, submarine cables do not cause a significant influence on the seabed environment in comparison to other activities in the sea. At the same time, it is not possible to say that their laying do not affect marine organisms. Reduced and limited but it is still an influence which is not equal to zero. In the case of the Arctic, it is of particular concern bearing in mind that the Arctic region is probably the most demonstrative example of environmental changes nowadays which clearly indicates that they are in progress ${ }^{55}$.

\section{SUBMARINE CABLES PROJECTS IN THE ARCTIC}

The issue of evaluating the process of laying submarine cables from the environmental point of view is interesting in the context of the activities states are conducting in the Arctic. There are currently several submarine cables already laid at the bottom of the ocean and several planned projects to construct submarine cables in the Arctic region. Global warming has led to the possibility of laying cables in the Arctic waters due to the reduction in the amount of ice and increased navigation capabilities ${ }^{56}$. The navigation season in the Arctic became longer which made laying cables in the Arctic possible.

The development of activities in the Arctic has always been among the priorities of the Arctic states, but now with the possibility to "discover" the Arctic in a new way such as laying submarine cables, the movement of states in this direction increased even more.

\footnotetext{
55 Olav Orheim "The Polar Oceans and Climate Change" in Davor Vidas, Peter Johan Schei, The World Ocean in Globalisation, Martinus Nijhoff Publishers. Leiden, Boston, 2011, pp. 147154, p. 148.

$56 \quad<$ https://www.scientificamerican.com/article/an-internet-cable-will-soon-cross-the-arcticcircle/> [Retrieved on 10 April 2018].
} 
According to the Russian Federation Strategy for the Development of the Arctic Zone designed for the period until 2020 , one of the priority directions for the development of the Arctic region is the creation of a modern information and telecommunications infrastructure ${ }^{57}$. In particular, it includes the use of fiberoptic and satellite communication systems for exploration of hydrocarbon areas on the continental shelf of the Russian Federation as well as the creation of an infrastructure providing communication services to public and business entities throughout the Arctic zone of the Russian Federation. It includes laying of submarine fiber-optic communication lines along the Northern Sea Route and integration with other states' communication networks.

The Canadian Telecommunications Act provides:

"telecommunications performs an essential role in the maintenance of Canada's identity and sovereignty" ${ }^{58}$

The Finnish government has recently issued a plan titled "Towards the Internet of Things: broadband implementation plan"59. The plan is promoting the development of fiber-optical lines connecting the territory of Finland.

Arctic states express the intention of a broadband development through submarine cables in the Arctic not only in their domestic policy but also in the documents developed by joint efforts. The report of the Arctic Council titled "Telecommunications Infrastructure in the Arctic" specifies:

\footnotetext{
57 See paragraphs 6,8(е), 11(д), 15(а), 15(в), 31(и) of the "Strategy of the development and provision of national security of the Russian Arctic zone for the period until 2020" elaborated in the framework of the State Program of the Russian Federation "Socio-economic development of the Arctic Region of the Russian Federation for the period until 2020", adopted by the resolution of the Government of the Russian Federation dated 21 of April 2014 №266 (available in Russian).

${ }^{58}$ Canadian Telecommunications Act, Telecommunications Act (S.C. 1993, p. 38), assented to 23 of June 1993, published by the Minister of Justice of Canada, section 7, <http://lawslois.justice.gc.ca> [Retrieved on 14 November 2018].

59 Towards the Internet of Things Broadband implementation plan, LVM/1022/07/2016, 1 June 2016 Ministry of Transport and Communications of Finland, <https://www.lvm.fi/lvm-site62mahti-portlet/download?did=206741> [Retrieved on 14 November 2018].
} 
"fiber-optic cable is the primary way Internet and other traffic is transmitted between continents or countries separated by the high seas".

It also underlines that in the Arctic:

"providers need to select their submarine fiber routes carefully, given the risk of ice scour in some areas, and to ensure reliable service backup plans to carry end-users' traffic if a submarine cable breaks during the winter months when weather conditions can make repair infeasible". ${ }^{60}$

Thus, there is a significant potential of constructing an extensive cable network in the Arctic, and it is widely discussed in the Arctic community. Especially provided the specific role of telecommunications facilities submarine cables can bring to the Arctic. Among them is access to telemedicine, online education, development of business and tourism, et cetera. Several cable projects will be further considered in this article.

\section{Completed projects}

There are submarine cables which have been successfully laid in the Arctic ocean. They are of local significance connecting neighboring states or parts of the state providing the local population with telecommunications services. For instance, a cable Greenland Connect landing at the southwestern coast of Greenland connecting it to Iceland and Canada with further connections to New York and Denmark ${ }^{61}$. The Baltic Sea cable with the length of five hundred fifty kilometers connecting Finland, Sweden, and Estonia is also an example of completed project fulfilled in the framework of a public-private partnership ${ }^{62}$.

Svalbard Undersea Cable System owned and operated by Telenor connects the mainland of Norway with Svalbard. The length of the cable is two thousand

60 Arctic Council Task Force on Telecommunications Infrastructure in the Arctic, 2017, Telecommunications infrastructure in the Arctic: a circumpolar assessment. Arctic Council Task Force on Telecommunications Infrastructure in the Arctic (TFTIA), 2017, p.44, $<$ https://oaarchive.arctic-council.org/bitstream/handle/11374/1924/2017-04-28-

ACS Telecoms REPORT WEB-2.pdf? sequence=1> [Retrieved on 14 November 2018].

${ }^{61}$ Arctic Council Task Force on Telecommunications Infrastructure in the Arctic...cit. p. 67. 62 <https://www.submarinecablemap.com/\#/submarine-cable/baltic-sea-submarine-cable> [Retrieved on 14 November 2018]. 
seven hundred fourteen kilometers. It came in service in 2004 and currently continues to provide broadband services to Norwegians ${ }^{63}$.

\section{Proposed projects}

The company Polarnet Project proposed to lay the cable titled ROTACS (the Russian Optical Transarctic Cable System) ${ }^{64}$. The cable should go along the Russian Arctic coast and connect Tokyo and London. Apart from connecting these two states as final destinations submarine cable shall also connect northern communities to the cable network and provide them with high speed and reliable Internet connection ${ }^{65}$.

The idea to lay a large-scale submarine cable belongs not only to the Russian side. Interest in the project of laying a submarine cable along the Arctic coast of the Russian Federation was expressed by other states such as China and Finland $^{66}$. The ROTACS cable concept, in particular, attracts Chinese side in the light of the Beijing's Belt and Road Initiative (BRI) adopted in China ${ }^{67}$. The Arctic component of this Initiative was discussed between China, Finland and Russia, where all parties expressed an interest in finishing the project:China in order to perform its plan and ensure financial as well as investments environment; Finland with a fundamental interest to achieve the connectivity for its northern territories; and Russia as the state through which maritime zones the cable is planned to be laid. Since the beginning of the 2000s, negotiations have been ongoing, even some exploratory works have been done, but the construction time has been repeatedly postponed, and at the moment the construction of the cable line has not started yet ${ }^{68}$.

By 2012 the Polarnet Project company was the first and the only company which has conducted comprehensive marine survey operations in the Arctic

$63<$ http://www.fiberatlantic.com/system/yPXEW> [Retrieved on 14 November 2018].

$64<$ http://www.polarnetproject.net/> [Retrieved on 14 November 2018].

65 <https://www.extremetech.com/extreme/122989-1-5-billion-the-cost-of-cutting-london-toykolatency-by-60ms> [Retrieved on 14 November 2018].

$66<$ http://pro-arctic.ru/05/05/2016/news/21410> [Retrieved on 14 November 2018].

$67<$ <https://www2.deloitte.com/insights/us/en/economy/asia-pacific/china-belt-and-roadinitiative.html> [Retrieved on 14 November 2018].

68 Elizaveta Titarenko, "Polarnet Proekt" zaruchilsya podderzkoi", in ComNews journal, vol.3107, 2017 (in Russian). 
with the aim to examine the possibility to lay submarine cable through the whole Arctic. After the work has been done, it became clear that the submarine cable system can be constructed in the Arctic realities. In October 2011 the Russian Governmental Commission for Federal Communications and Information Technology granted its permission to conduct the project which has been evaluated as an essential for Russian interests ${ }^{69}$. The current state of the cable is characterized by the statement of Polarnet Project to finish the project by $2020^{70}$.

One of the alternative projects is the Eastern Arctic Undersea Fiber Optic Network (EAUFON) ${ }^{71}$ which is not yet in force. In February 2018 the company WFN Strategies under which initiative the cable is planned has received a contract by Kativik Regional Government (Canada) to provide cable route survey for the proposed Eastern Arctic Undersea Fibre Optic Network (EAUFON) submarine telecoms cable system ${ }^{72}$. EAUFON is planned to connect multiple communities in Canada's Nunavik region. The preliminary date to put the cable into service is scheduled for 2020.

Mackenzie Valley And Dempster Highway Fiber project along the Mackenzie Valley and Beaufort Delta, as well as Midgardsormen, a Norwegian project seeking to construct a Norway-centric transatlantic cable system to connect Norway and Sweden to the East Coast of the United States are examples of submarine cable initiatives in the $\operatorname{Arctic}^{73}$. Norilsk Fiber Optic Broadband initiated by the Russian state-owned company Nornickel and Nxtvn'S Oulu Nordic Express in the Nordic regions of Finland and Sweden to Norway are also examples of extending a submarine cable network in the $\operatorname{Arctic}^{74}$.

\footnotetext{
$69<$ http://subtelforum.com/77zao-polarnet-project-invites-tenders-for-russian-optical-trans-arcticsubmarine-cable-system/> [Retrieved on 14 November 2018].

$70<$ http://www.polarnetproject.net/> [Retrieved on 14 November 2018].

71 Michael Delaunay, "Briefing Note Submarine Cables: Bringing Broadband Internet to the Arctic, a Life Changer for Northerners?”, in Arctic Yearbook 2017, vol.1, 2017.

$72<$ https://subseaworldnews.com/2018/02/21/wfn-strategies-nets-eaufon-subsea-cable-surveydeal/> [Retrieved on 14 November 2018].

$73<$ https://mvflproject.com/project-details/> [Retrieved on 14 November 2018].

74 Telecommunications Infrastructure Working Group of the Arctic Council, "Arctic Broadband: Recommendations for an Interconnected Arctic", Arctic Economic Council, 2016, $<$ https://arcticeconomiccouncil.com/wp-content/uploads/2017/02/AEC-Report Final-LR-1.pdf> [Retrieved on 14 November 2018], p. 24.
} 
Along with the cables mentioned above, the intention to lay the submarine cable under the title Ivaluk Network project was expressed by the Canadian company Nuvitik Communication in $2014^{75}$. However, to date, it has not been laid, and its route has not appeared on the submarine cables map ${ }^{76}$. It should have involved three sections: Nunavik, Southeast Nunavut, and Northwest Nunavut. Each section should have connected every coastal community on its path of going through the Arctic territories ${ }^{77}$. The installation was planned to include two phases, with the Nunavik and Southeast Nunavut network routes operational by fall of 2016 and the Northwest installation planned for 2017. However, the project was stopped due to the following reasons. A telecommunications company Arctic Fibre began it, but in May 2016, Arctic Fibre announced that Quintillion Subsea Holdings had acquired its assets ${ }^{78}$.

\section{The current project of Quintillion Subsea Cable System}

An alternative project of laying a submarine cable in the Arctic titled the Quintillion Subsea Cable System is planned by the company Quintillion. It deserves special attention because in contrast to all other cables already in force or those planned to be laid in future the Quintillion Subsea Cable System is the ongoing initiative. In addition, it is the first large-scale project planned to go through the whole Arctic and connect many states in the framework of a single project which is already under construction.

The company Quintillion acquired the previously mentioned cable Ivaluk Network project and continued this initiative to lay the first large-scale submarine cable in the $\operatorname{Arctic}^{79}$. The project consists of three segments. The first is Alaska segment (connecting several territories in Alaska), the second is the Pacific segment (will connect Alaska with Japan), and a segment

\footnotetext{
${ }^{75}$ Michael Delaunay, "The Arctic: A New Internet Highway?", in Arctic Yearbook 2014, vol.1, 2014.

${ }^{76}<$ https://www.submarinecablemap.com/> [Retrieved on 14 November 2018].

$77<$ http://nuvitik.ca/> [Retrieved on 14 November 2018].

78 Telecommunications Infrastructure Working Group of the Arctic Council, "Arctic Broadband: Recommendations for..." cit. p. 40.

${ }^{79}$ See the website of the company constructing the cable <http://qexpressnet.com/system/> [Retrieved on 14 November 2018].
} 
connecting Alaska to Europe via the Canadian Arctic (in particular through the Northwest Passage to the United Kingdom $)^{80}$. The first part of the submarine cable titled "Alaska", a one thousand two-hundred-mile fiber-optic line off the coast of Alaska, has already been put into effect. In other words, this section of a cable started transmitting signals and provide local communities with telecommunications. Initially, the introduction of the first segment was planned for December 2017, but since November 2016 the cable has been running in a test mode ${ }^{81}$. The second section titled "Asia" is planned to be laid in Western Asia and will allow connecting Asia with the United States. The third section "Canada-United Kingdom" is designed to expand the cable system further and enable the northern territories of Canada to be added to the network. The cable is laid and will be owned by private company Quintillion ${ }^{82}$, registered in the United States, Alaska, but will pass through the maritime areas of several states, including Japan, the United States, Canada, and the United Kingdom.

Since the first phase of the cable has been already completed, it is of interest to have a look at the environmental requirements followed by the cable constructor and how they could affect the Arctic environment.

\section{ENVIRONMENTAL LAW ASPECT OF QUINTILLION SUBSEA CABLE SYSTEM}

The impact of submarine cables to the environment is commonly accepted to be benign. However, the international environmental law is constantly under development, and new approaches and principles have been evolved within its framework. Nowadays it is necessary to take into account that the impact of submarine cables on marine organisms has not been sufficiently investigated yet. There is still uncertainty in the impact of electromagnetic fields and thermal

\footnotetext{
80 Telecommunications Infrastructure Working Group of the Arctic Council, "Arctic Broadband:.." cit. p.25.

81 See Elizabeth Pierce's (Founder and CEO of the Quintillion company) presentation for the Arctic Economic Council, <https://arcticeconomiccouncil.com/wpcontent/uploads/2017/06/TOW-Summit-Pierce.pdf> [Retrieved on 14 November 2018].

82 Section "Corporate profile" <http://qexpressnet.com/corporate-profile/> [Retrieved on 14 November 2018].
} 
radiation on organisms ${ }^{83}$, and therefore, the possible significant negative impact of submarine cables cannot be excluded.

Regarding the construction and use of submarine cables in the Arctic, this issue becomes even more complex given the unique climate conditions of the Arctic region and the lack of appropriate practices. Submarine cables like Quintillion Subsea Cable System have never been laid there before. Thus, there is uncertainty and lack of scientific knowledge of how the marine environment will be influenced. The laying of a submarine cable in the Arctic waters differs from laying of a cable in normal seabed conditions and temperatures. Since many submarine cables were laid in different parts of the oceans, there is enough experience and research collected on the consequences of cable laying. However, it is different from the Arctic region realities.

The peculiarities of the Arctic are explained first of all by climate conditions and remoteness of the area. The navigation season in the period of open ice, when a cable ship can perform its work is short in the Arctic. It explains the necessity to perform the continuing operations in this short period. The process of laying a cable on the seabed becomes uninterrupted and by this increases the stress on the marine environment. As a result, more irritating effects on the environment can occur. Apart from a short period of navigation, there are also limited opportunities for the supply of special mechanisms, including remotely operated vehicles that facilitate the laying of cables on the seabed. Additional protection for the buried submarine cable is also a necessity in the Arctic. Such protection is made with the purpose to prevent damage by ice and stipulates for longer presence of remotely operated vehicles on the seabed in contrast to projects of laying submarine cable in non-extreme conditions. Thus, the postulate about the minimal effect from submarine cables to the environment cannot be automatically transferred to the Arctic only by the principle of analogy.

${ }^{83}$ OSPAR Commission, "Assessment of the environmental impacts..." cit. pp.6-12. 


\title{
1. Application of the precautionary principle
}

The applicability of the precautionary principle to planned submarine cables in the Arctic deserves special attention. The Declaration of Rio de Janeiro contains a general understanding of the principle and recognizes this principle as the principle of environment and development:

\begin{abstract}
"In order to protect the environment, the precautionary approach shall be widely applied by States according to their capabilities. Where there are threats of serious or irreversible damage, lack of full scientific certainty shall not be used as a reason for postponing cost-effective measures to prevent environmental degradation." ${ }^{84}$
\end{abstract}

The precautionary principle is currently widely applied in the light of the problems of pollution of the marine environment and conservation of marine living resources ${ }^{85}$ but might successfully apply to submarine cables activities ${ }^{86}$.

Before the first part of the Quintillion cable was laid, the company Quintillion received a response to its project from the United States Department of Commerce, the National Oceanic Atmospheric Administration ${ }^{87}$, which assessed the impact of the cable on local fauna. Since the first section of the cable ("Alaska") was laid only in the United States' maritime zones, the review of this authority was needed for the realization of the project. Even though the

\footnotetext{
${ }^{84}$ Yuriy Michailovich Kolosov, Emilia Semenovna Krivchikova, Deistvuychee mezdunarodnoe pravo, Izdatelstvo Moskovskogo nezavisimogo instituta mezdunarodnogo prava. Moscow,1999. 85 See London Protocol of 1996 to the Convention on the Prevention of Marine Pollution by Dumping of Wastes and Other Matter, adopted 13 of November 1972, entered into force 30 of August 1975, 26 UST 2403, 1046 UNTS 120, 11 ILM 1294 (1972); Provisions of the Agreement relating to the implementation of Part XI of the United Nations Convention on the Law of the Sea 1982 relating to the conservation and management of straddling fish stocks and highly migratory fish stocks; Convention for the Protection of the Marine Environment of the North-East Atlantic (OSPAR Convention), concluded 22 September 1993, entered into force 25 March 1998, 2354 UNTS 67; 32 ILM 1069 (1993) and other international agreements.

${ }^{86}$ OSPAR Commission, "Assessment of the environmental impacts...cit. p.15.

87 United States Department Of Commerce, National Oceanic Atmospheric Administration, Endangered Species Act Section 7(a)(2) Biological Opinion on the proposed Subsea Fiber Optic Cable-laying Activities and Associated Proposed Issuance of an Incidental Harassment Authorization in the Bering, Chukchi, and Beaufort Seas, Alaska, NMFS Consultation Number: AKR-2016-9555 <https://alaskafisheries.noaa.gov/sites/default/files/quintillionihabiop51816.pdf> [Retrieved on 14 November 2018].
} 
permit was finally issued in accordance with the Endangered Species Act ${ }^{88}$, it follows from the text that, according to some indicators, it is not completely clear how the cable system will affect the environment, in particular, in the long term $^{89}$. Despite the fact that in the report it is mentioned that neither none of the species of living organisms will be destroyed nor their habitual way of life will be seriously changed, it is necessary to take a closer look at this document.

In the report, the following species of animals which will be adversely affected are mentioned: blue whale, humpback whale, sperm whale, ringed arctic seal, sea lion, and others. Some of them are given a special status of endangered species. For instance, seals are listed in the Red Book of the Russian Federation $^{90}$ which specifies the species that need special protection due to their vulnerability. The WWF flagship species also include various species of whales $^{91}$. The document proposes to issue a permit for laying the submarine cable and designates the permissible norms for the number of accidental deaths of the above-mentioned living organisms that cannot be exceeded by Quintillion. For example, unintended mortality of no more than five ringed and five bearded seals are allowed in the process of installation of the submarine cable $^{92}$.

During the laying of the Quintillion cable, the following impact is caused to the Arctic ecosystem, which can lead to irreversible consequences. The light and loud sound of cable ship's mechanisms and remotely operated vehicles, disrupting the habitual way of life of marine organisms, as well as the vibration present when laying the cable on the seabed, which forces living organisms to

88 United States Department Of Commerce, National Oceanic Atmospheric Administration, Endangered Species Act... cit. p.6.

${ }^{89}$ Alison Weisburger, "Planned Undersea Fiber-Optic Cable Projects in Arctic as Allegory for Changing Region", in The Arctic Institute, Centre for Circumpolar Security Studies, 2012, $<$ https://www.thearcticinstitute.org/planned-undersea-fiber-optic-cable/> [Retrieved on 14 November 2018].

90 Victor Ivanovich Danilov-Danilyan, Krasnaya kniga Rossiyskoi Federacii (zhivotnye), Astrel. Moscow, 2001.

91 See WWF website, section "Endangered species", $<$ http://www.wwf.ca/conservation/species/endangered species/> [Retrieved on 14 November 2018].

92 United States Department Of Commerce, National Oceanic Atmospheric Administration, Endangered Species Act... cit. p.49. 
leave their habitual environment and migrate away from ordinary places ${ }^{93}$. Even after the completion of the work on laying the submarine cable, it takes time to return to their normal way of life. Stress, experienced by animals from changing their natural life, can affect the reproductive function and ability to survive. The entanglement of animals in the submarine cable is also possible.

When installing the cable, it is likely to cause harm and death to living organisms in the immediate vicinity of the cable system. Thus, a seabed line approximately a meter wide, where the cable is directly laid, will be affected and those marine organisms that are on the bottom will be destroyed. In addition, larger animals, including seals, whales, birds and other organisms that are protected by international conventions are at risk to be injured by propeller blades and the engine of cable laying ships. The installation of the submarine cable will last 24 hours a day until the installation of an entire segment of the submarine cable section is completed ${ }^{94}$.

Recognizing the increased risk of harm to the environment, Quintillion has proposed the following measures aimed at reducing such risk. To avoid concentrations or groups of whales/sea lions by maneuvering around them, take reasonable precautions to avoid potential interactions with all marine mammals observed within 1.6 kilometers (1 mile) of the cable ship, to reduce the speed to 9.3 kilometers per hour or less in case of adverse weather conditions ${ }^{95}$ (such as reduced visibility) to avoid the probability of collision with whales and other species. It is also proposed to use the developed system of observation of marine mammals in order to study their behavior and reaction to cable operations.

However, though measures are proposed, the mechanism for monitoring and control of their implementation is not established clearly. For instance, some

\footnotetext{
${ }^{93}$ United States Department Of Commerce, National Oceanic Atmospheric Administration, Endangered Species Act... cit. p.61.

${ }_{94}$ United States Department Of Commerce, National Oceanic Atmospheric Administration, Endangered Species Act... cit. p. 10.

95 United States Department Of Commerce, National Oceanic Atmospheric Administration, Endangered Species Act... cit. p.17.
} 
measures, such as photo and videography of animals to fix their behavior and reaction are made if the necessary equipment is available (in other words, optional $)^{96}$. It is also noted that since anthropogenic influence during cable laying process on the seabed may have a different effect on living organisms depending on their individual characteristics, a possible adverse effect on some individuals is unknown and might be worse than expected ${ }^{97}$. Icebreakers represent additional threats, for example, for bearded and ringed seals living in the Arctic because they can damage them by ship's turbines and blades $^{98}$. Vessels can destroy these species, their rookeries and affect animals by the noise spreading through air or water. The document states that discharge of harmful substances (for example, ballast water containing oil or oil detergents used for washing decks, hydraulic fluids, motor fuel, et cetera) is possible. It is mentioned that if such discharge occurs, the amount of leaks of harmful substances is supposed to be small. However, no guarantee for this is given by the Quintillion. Precipitation resulting from the burying of the cable will temporarily affect the quality of water during the project activity. For most of the proposed activities, Quintillion assumes that this impact will occur in the area immediately surrounding the submarine cable (from a few to tens of meters) and such precipitation will quickly settle on the seabed (i.e., within a few hours). However, this is only an approximate estimate, given by the cable-laying company itself, which cannot be completely reliable. In this case, the use of the precautionary principle when laying submarine cables in the Arctic and effective control of its implementation by Arctic states is justified and necessary to prevent the negative consequences.

\section{The Polar Code requirements for cable ships}

After the adoption of the Polar Code ${ }^{99}$ by the International Maritime Organization, which came into force in 2017, measures at the international level

\footnotetext{
96 United States Department Of Commerce, National Oceanic Atmospheric Administration, Endangered Species Act... cit. p.23.

97 United States Department Of Commerce, National Oceanic Atmospheric Administration, Endangered Species Act... cit. p.41.

98 United States Department Of Commerce, National Oceanic Atmospheric Administration, Endangered Species Act... cit. p. 49.

99 International Code for Ships Operating in Polar Waters (Polar Code) $<$ http://www.imo.org/en/MediaCentre/HotTopics/polar/Pages/default.aspx> [Retrieved on 14 November 2018].
} 
to reduce the risks to the environment arising from cable-laying vessels and their activities in the polar waters (of the Arctic and Antarctica) were adopted. The Polar Code supports the provision on the licensing of vessels for navigation in Arctic waters (following the idea specified in the Article 234 of the LOSC). The Code divides all vessels navigating in the polar regions into three groups $(A, B, C)$ and introduces safety requirements with respect to pollution from ships. One of the relevant rules is the obligation to have a Polar Ship Certificate (section 1.3.1 of Part I A of the Polar Code). The issuance of such a certificate implies the verification of documentation and the inspection of the vessel (section 1.3.2). A certificate can also be issued without inspection, but only on the basis of the relevant documents submitted (and only for freight vessels of category C) (section 1.3.3). The Polar Code gives the right to issue such certificates to both the Arctic states and the flag states of the vessel, which is also an innovation. Before the adoption of this Code, permission for navigation in polar waters could be given only in the framework of the implementation of rights of the Arctic states. This rule relating to the flag states causes concerns. Non-Arctic states might have no experience of navigation in polar waters. Whether they can adequately assess the ship's readiness for the corresponding activity is an open question.

Cable vessels engaged in the processes of laying, repairing and removing submarine cables can also be considered as an inherent component of the projects of cable construction. Along with submarine cables themselves and remotely operated vehicles which have direct contact with the seabed, cable vessels perform essential functions to support the whole activity. Thus, legal requirements for the operations of cable vessels are also an instrument to ensure the protection of the marine environment.

Cable-laying vessels contracted for laying the Quintillion cable system are not an exception and should also receive appropriate certificates and permits required by the Polar Code. In particular, the French vessels "Ile de Batz"100,

100 Jim Paulin, "Fiber-laying ship calls on internet-starved Aleutians", in Alaska Journal of Commerce, vol. 07/12/2017, 2017. 
"lle de Brehat" and "lle de Sein"101, chartered by Quintillion to install different parts of the Quintillion Subsea Cable System, should follow the rules of the Polar Code.

Climatic features of the Arctic region dictate their conditions and make adjustments to the installation of the cable system. Thus, to finish a particular stage of work before the end of the navigation season, the cable-laying vessel in the Arctic should work almost without stops. This means the use of the increased capacities of the vessel itself, the crew, personnel, and remotely operated vehicles, which are used for direct cable installation on the seabed. In order to reduce the likelihood of damage to the ecology, the Arctic vessels should be tested for frost resistance and stability of mechanisms in Arctic conditions. It allows reducing the risk of fuel spills and accidents due to the inoperability of the vessel in conditions of low temperatures and extended operations. The Code also provides with the more detailed process (in comparison with the MARPOL Convention ${ }^{102}$ ) of collecting garbage left after the vessel's stay in the Arctic waters ${ }^{103}$. In the process of burying a submarine cable in the trench, garbage, stones, and other objects may appear. Therefore, such garbage and waste of used materials from cables polluting the environment must be exported outside the Arctic.

Generally, the Code is based on the application of a risk assessment approach, one of which is the sensitivity of the environment to harmful substances and other types of exposure, as well as the need for its long-term recovery.

All mentioned above applies to projects of submarine cables in the Arctic. A relatively new activity shall be taken under control first of all by joint efforts of the Arctic states, and effective mechanisms of control of the implementation of the precautionary principle as well as the provisions of the Polar Code shall be

\footnotetext{
101 United States Department Of Commerce, National Oceanic Atmospheric Administration, Endangered Species Act... cit. p.10.

102 International Convention for the Prevention of Pollution from Ships (MARPOL 73/78), concluded 11 February 1973, entered into force 10 February 1983, 12 ILM 1319 (1973); TIAS No. 10,561; 34 UST 3407; 1340 UNTS 184.

${ }^{103}$ Polar Code, Chapter 5.
} 
elaborated. For instance, within the Arctic Council ${ }^{104}$ which up to date has not dedicated much attention to the increasing submarine cable industry in the Arctic.

\section{CONCLUSION}

Over time, the activities in the Arctic region have been developing and gradually introducing new forms of using the Arctic waters. With the time and development of new technologies permitting to discover the Arctic region from different perspectives, such new forms received an opportunity to be implemented. One of the new forms of Arctic use along with, for instance, currently developing Arctic tourism ${ }^{105}$, is submarine cable activities. They receive more attention from business, governments, and scientific community and ideas to lay submarine cables through the Arctic become more popular. It requires a new assessment of the existing legal regulation in the Arctic at both regional and international levels through the cooperation and joint efforts of Arctic states.

The connection of Arctic communities to the global submarine cable network is of great importance and high priority from the social point of view. On the one hand, fast and reliable Internet access for remote territories facilitates their development, promotes cultural and educational values and makes the connectivity easier. On the other, the environmental side of the question remains unclear and is not thoroughly examined yet. However, following the carefully developed strategy of balancing social needs and the environmental knowledge, both aims can be achieved: bringing the connection facilities to the Arctic without damage to the marine environment.

The norms of the LOSC provide with a general regime for laying and using submarine cables. They do not distinguish the Arctic from other parts of the

\footnotetext{
${ }^{104}$ See website of the Arctic Council <https://arctic-council.org/index.php/ru/> [Retrieved on 14 November 2018].

105 Arctic Marine Tourism Project (AMTP), Best Practice Guidelines, April 2015 $<$ https://oaarchive.arctic-

council.org/bitstream/handle/11374/414/AMTP\%20Best\%20Practice\%20Guidelines.pdf?sequen ce=1\&isAllowed $=y>$ [Retrieved on 14 November 2018].
} 
World Ocean. However, the Arctic has a unique and vulnerable environment which shall be protected in a specific way. As far as environmental aspect is concerned, the modern development of both science and technology should be examined comprehensively, and both the law of the sea as well as the environmental law shall be taken into account while implementing the projects of laying submarine cables in the Arctic.

The precautionary principle has become a part of the international legal regulation dealing with the protection of the environment, including the oceans. It applies to matters of pollution of the marine environment and conservation of marine living resources which are the issues traditionally covered by the law of the sea. However, there is no mention of the applicability of the precautionary principle to the activities relating to submarine cables because they are recognized to be friendly to the marine environment. At the same time, it appears that when carrying out activities to lay submarine cables, it also has sufficient grounds to apply, especially in Arctic waters. Notwithstanding local and small negative impact from submarine cables projects evaluated nowadays, there are particular concerns on how this impact will be reflected in future. Thus, the precautionary principle can be considered as a measure necessary to apply for carrying out cable related activities in the Arctic with the following control by Arctic states. It seems that the experience of laying the Quintillion Subsea Cable System can be taken into account for the implementation of further projects of laying submarine cables in the Arctic. Especially, bearing in mind the importance of telecommunications for the development of the Arctic region and steadily increasing interest to build connectivity infrastructure from the side of Arctic states.

\section{BIBLIOGRAPHY}

1. Beckman, Robert, "Submarine Cables - A Critically Important but Neglected Area of the Law of the Sea", paper presented at 7 the International Conference on Legal Regimes of Sea, Air, Space and Antarctica, 15-17 of January 2010, New Delhi. 
2. Burnett, Douglas; Davenport, Tara; Beckman, Robert, Submarine cables: The Handbook of Law and Policy, International Martinus Nijhoff. Leiden, 2014.

3. Burnett, Douglas, "Note to Navy: It's time to pay attention to security for undersea cables-crucial to global communications and commerce, and vital to our national interests", in Proceedings Magazine of the US Naval Institute, vol. 137/8/1,302, 2011.

4. Burnett, Douglas, "Recovery of Cable Repair Ship Cost Damages from Third Parties That Injure Submarine Cables", in Tulane Maritime Law Journal, vol. 35, 2010.

5. Butler, Rhett, eds., "The scientific and societal case for the integration of environmental sensors into new submarine telecommunication cables", Joint Task Force on Green Cables ITU/WMO/UNESCO/IOC publication, 2014.

6. Colombos, Constantine John, The International Law of the Sea (Russian translation), Progress. Moscow, 1975.

7. Carter Lionel. Burnett, Douglas. Drew, Stephen. Marle, Graham. Hagadorn, Lonnie, Deborah Bartlett-McNeil D., Nigel Irvine, "Submarine Cables and the Oceans - Connecting the World", in UNEP-WCMC Biodiversity Series, vol. 31, 2009.

8. Collins, Norval, "Assessment of Potential Ecosystem Effects from Electromagnetic Fields (EMF) Associated with Subsea Power Cables and TISEC Devices in Minas Channel", prepared by CEF Consultants Ltd. for Fundy Ocean Resource Centre for Energy (FORCE), Halifax, 2012.

9. Conway, Maura. Jarvis, L. Lee. Orla, Leha, "Terrorists' Use of the Internet: Assessment and Response", in NATO Science for Peace and Security Series E: Human and Societal Dynamics, vol.136, 2017.

10. Danilov-Danilyan, Victor Ivanovich, Krasnaya kniga Rossiyskoi Federacii (zhivotnye), Astrel. Moscow, 2001.

11. Davenport, Tara, "Submarine Cables, Cybersecurity and International Law: An Intersectional Analysis", in Catholic University Journal of Law and Technology, vol. 24, 2015.

12. Delaunay, Michael, "The Arctic: A New Internet Highway?", in Arctic Yearbook 2014, vol.1, 2014. 
13. Delaunay, Michael, "Briefing Note Submarine Cables: Bringing Broadband Internet to the Arctic, a Life Changer for Northerners?", in Arctic Yearbook 2017, vol.1, 2017.

14. Ekwere, Kingsley, "Submarine Cables and the Marine Environmental: Enhancing Sustainable and Harmonious Interactions", in China Oceans Law Review, vol. 2016, 2016.

15. Guseva, Elena, "Istoriya podvodnogo cabelestroyeniya", in Cable-news journal, vol.4, 2010.

16. Heezen, Bruce C.; Johnson, Leonard G., "Alaskan Submarine Cables: A Struggle with a Harsh Environment", Arctic, vol. 22, No. 4, 1969.

17. Howe B., Panayotou K., "Harnessing submarine cables to save lives", The UNESCO Courier, e-ISSN 2220-2293, 2017.

18. Kogan, Irina. Paull, Charles. Kuhnz, Linda. Burton, Erica. Von Thun, Susan. Greene, H. Gary. Barry, James, "ATOC/Pioneer Seamount cable after 8 years on the seafloor: Observations, environmental impact", in Continental Shelf Research, vol. 26, 2006.

19. Kolosov, Yuriy Michailovich; Krivchikova, Emilia Semenovna, Deistvuychee mezdunarodnoe pravo, Izdatelstvo Moskovskogo nezavisimogo instituta mezdunarodnogo prava. Moscow,1999.

20. Mudrić, Miso., "Rights of States regarding underwater cables and pipelines", in Australian resources and energy Law Journal, vol. 29, 2010.

21. Nordquist, Myron; Nandan, Satya; Rosenne Shabtai, eds., United Nations Convention on the Law of the Sea 1982: A Commentary, vol.II, Martinus Nijhoff Publishers. Netherlands, 1993.

22. Nordquist, Myron; Nandan, Satya, Rosenne, Shabtai eds., United Nations Convention on the Law of the Sea 1982: A Commentary, Martinus Nijhoff Publishers. Dordrecht, Boston and London, vol. III, 1993.

23.Olav Orheim "The Polar Oceans and Climate Change" in Davor Vidas, Peter Johan Schei, The World Ocean in Globalisation, Martinus Nijhoff Publishers. Leiden, Boston, 2011.

24. Paulin, Jim, "Fiber-laying ship calls on internet-starved Aleutians", in Alaska Journal of Commerce, vol. 07/12/2017, 2017.

25. Perez-Alvaro, Elena, "Unconsidered Threats to Underwater Cultural Heritage: Laying Submarine Cables", in Rosetta, vol.14, 2013. 
26. Proelss, Alexander, United Nations Convention on the Law of the Sea: A Commentary, 1st edition, Leiden: Beck/Hart/Nomos, 2017.

27. Titarenko, Elizaveta, "Polarnet Proekt" zaruchilsya podderzkoi", in ComNews, vol.31-07, 2017 (in Russian).

28. Van Logchem, Youri, "Submarine Telecommunication Cables in Disputed Maritime Areas", in Ocean Development and International Law, vol. 45, 2014.

29. Weisburger, Alison, "Planned Undersea Fiber-Optic Cable Projects in Arctic as Allegory for Changing Region", in The Arctic Institute, Centre for Circumpolar Security Studies, 2012.

30. Worzyk, Thomas, Submarine Power Cables: Design, Installation, Repair, Environmental Aspects, Springer. Dordrecht, Heidelberg, London, New York, 2009. 